UDC 338.1:346.3

http://doi.org/10.21272/mmi.2019.3-08

JEL Classification: M21, D21, C12

Lubos Elexa,

Ph.D., Assistant Professor, Matej Bel University, Slovakia

Lenka Hvolkova,

Ph.D., Assistant Professor, Matej Bel University, Slovakia

Miroslava Knapkova,

Ph.D., Assistant Professor, Matej Bel University, Slovakia

\title{
ANTICRISIS MANAGEMENT: WARNING SIGNALS BEFORE FAILURE
}

Abstract. Critical situations in the operations of companies, both evitable and inevitable, usually have a certain pattern and development trend but are different as to the duration, sector or region. Many of them ask for some legal procedure, the most critical ones lead to a bankruptcy process. The purpose of the research is the rapid increase in number of bankruptcies in Slovakia in recent years. The main aim of this paper is to analyse the evolution of the bankruptcy as a type of critical situation in Slovak companies and specify it according to the regional and sectoral perspective, including economic conditions prior to a bankruptcy. The paper utilizes secondary data obtained from available databases. The initial analysis is focused on the group of all companies entering the bankruptcy process in the period from 2009 until 2019. Firstly, the full sample is considered, regardless of the legal form and data and the outcome of the analysis is used for mapping of industrial and regional intensity of bankruptcies. The second stage of the research is focused on research sample after the irrelevant subjects were ousted from it. As irrelevant subjects we consider sole traders without business data and companies with doubtful data or unclear bankruptcy start. Through the available indicators are identified the early warning signals from the financial perspective. Indicators are split into two categories - absolute and relative ones and they are investigated three, two and one years before the start of bankruptcy. Four hypotheses were formulated before the research, the length of bankruptcy process was quantified and specified for SK NACE sectors and regions. The paper presents the results of empirical analysis, which showed that the dynamic change in number of bankruptcies was brought with significant amending of bankruptcy legislation. The longest bankruptcy process is found in accommodation and food services (4 years), while IT companies generally went bankrupt within a year. The economic situation in bankrupting companies significantly worsen in case of sales and equity (the number of companies with negative equity doubled), development of profitloss fluctuate a bit due to the sale of assets which helped in later stages. There is no statistically significant difference in the length of bankruptcy among the industries and regions. In case of legislative rules the lower cash ratio seems to be the dominant reason while companies enter the bankruptcy. The research results can be useful for further and more detailed analysis, mostly in connection with bankruptcy development (what happen when bankruptcy started) and liabilities compensation and through non-financial bankruptcy factors in individual industries.

Keywords: bankruptcy, failure, indebtedness, internal factors, life cycle, liquidity.

Introduction. Business life cycle always heads towards certain end and gets through several stages that may repeat over time, have flexible duration, periodicity, etc. The development of industries and economics is similar, as they consist of businesses, although their end is not so probable and ultimate and development is long-term. The start-up era brought certain dynamics into the life cycle of companies and in certain way, they shortened the length of business cycles. On the other hand, their end is usually connected with exit strategies of former owners or further expansion after the merger or acquisition, thus it is not always the real end of the business itself or its primary idea.

There are several types of business ends in Slovak legislation, including liquidation specified by Civil Code and Business Code, bankruptcy specified by Bankruptcy Act and final erasure from the Business register as definite administrative end. The main aim of this paper is to analyse the evolution of bankruptcy as a type of critical situation in Slovak companies according to the regional and sectoral perspective. It describes the intensity of bankruptcies from 2009 until 2019 with appropriate differentiation as to the

Cite as: Elexa, L., Hvolkova, L., Knapkova, M. (2019). Anticrisis Management: Warning Signals Before Failure. Marketing and Management of Innovations, 3, 98-111. http://doi.org/10.21272/mmi.2019.3-08 
Slovak regions and SK NACE sectors, including economic life of bankrupted companies. Within shorter period from 2013 until 2019 it analyses the evolution of economic and financial conditions with focus given to three years before the start of bankruptcy. Absolute and relative indicators help to understand warning signals and initiators of bankruptcy. Within the paper, three independent hypotheses will be tested.

We consider bankruptcy as an inevitable part of each economics, although it usually does not occur all of a sudden, so there may exist the possibility of how to avoid it. Thus the understanding of the prebankruptcy cycle might help to understand the warning signals and, eventually, to adopt necessary measures (if possible). The conclusions presented in this paper are just a partial set of outcomes that are elaborated within more complex research in the project VEGA no. 1/0468/18.

Literature Review. The early literature on corporate failure connected this situation with bankruptcy defined as a legal term where business operations are terminated under the specific legal framework. According to Tobback et al. (2017), the term bankruptcy is used interchangeably with failure and default, where the notion of bankruptcy refers to the legal status of the entity when it cannot repay its owed debts. Bryan et al. (2013) add that bankruptcy is important fact of life in the modern business environment and occurs when the company is unable to meet its obligations and applies to a federal court either for a period of relief to reorganize its debts or to liquidate its assets. It has an extremely disruptive effect on the company undergoing bankruptcy and also on its various stakeholders such as employees, creditors, suppliers and customers. However, later research in this area was mostly oriented on the term financial distress, usually used to express financially troubled companies and as a mediator between the financial soundness and bankruptcy (Farooq et al., 2018). Purnanandam (2008) argues that financial distress is a state where companies do not have enough proceeds to pay their financial obligations while at the maturity they become insolvent. When creditors take legal action then the court may officially declare default company as bankrupt. In other words, financial distress is a leading indicator of failure and provides the early signal of expected bankruptcy.

It is postulated that healthy companies first face profitability problems and their continuity results in liquidity problems. Afterwards, continual losses and liquidity problems lead to severe liquidity where company does not hold enough assets to meet its financial obligations. Eventually, the company is liquidated to meet creditors' claims. It is also proposed that companies could recover at any stage of distress but with varying likelihood. It is further argued that as the financial distress becomes adverse, recovery becomes more difficult. Therefore, in the later stages of financial distress the company is less likely to become healthy again (Farooq et al., 2018). Various studies have endeavoured to identify the causes of corporate bankruptcy which can be as numerous and complex than factors leading growth. Korol and Korodi (2010) report that no single factor is responsible for the company's bankruptcy. There is a consensus on the existence of two groups of factors. The first involves endogenous causes, which occur within a company and are related to inefficient asset allocation, to an inefficient funding structure, and/or inadequate company management. The second group refers to exogenous causes, which consist of phenomena related to a country's general economic situation and with the fiscal, monetary, and exchange rate policies of the government authority. Companies cannot influence these factors. However, such factors affect companies' financial situation.

A comprehensive vision of the possible causes of failure was provided by Bradley and Rubach (2002) who remind the different families of the factors identified as causes of insolvency. Management, marketing, or financial reasons are the main ones but should be precise as additional elements intervene, such as the following:

- outside business conditions: includes an increase in competition, insurance, and general costs of doing business,

- financing: includes loss of capital, inability to secure new capital, and high debt, 
- inside business conditions: includes management mistakes, location, loss of clients, and trade credit problem,

- tax: includes problems with the tax administration,

- disputes with a particular creditor: includes foreclosures, lawsuits, and contract disputes,

- personal: includes illness and divorce,

- calamities: includes fraud, theft, natural disasters, and accidents,

- other: includes buying time and involuntary bankruptcy filings.

Ooghe and Waeyaert (2004, as cited in Ooghe and Prijcker, 2006) have created a conceptual failure model that expounds the different causes of failure and stresses the mutual relations between them (Figure 1). First, the general environment clusters several external causes. They affect managers' motivation, the usefulness of their skills and hence corporate policy, next to the relationship with stakeholders in their immediate environment. The immediate environment forms the second group of causes. The interactions between a company and its stakeholders determine corporate development. Ruinous competition, but also mutual projects with stakeholders are well-known examples of these interactions. Third, the characteristics of management or the entrepreneur and fourth, the company's corporate policy have a more important impact on performance (Boeker, 1997) and are therefore displayed in the centre of the model. Management, the third factor, is recognized as a major cause of bankruptcy Inappropriate management qualities and skills are a threat to firm's survival and are therefore often linked with the failure of start-ups. If these managers are, in addition, reluctant to accept advice from other parties, they significantly reduce company's long term survival chances. It is furthermore remarkable to which extent personal characteristics affect performance, e. g. through optimism and risk-seeking behaviour that may also precede distress (Parrino et al., 2005). Finally, company characteristics: size, maturity, industry and flexibility also have to be taken into account.

First studies in the area of business failure emphasized to forecast the ex-ante event of legal bankruptcy such as Altman's model. However, later research criticized these studies due to their contextual application (Pindado et al., 2008) and ex-post approach (Opoku et al., 2015) that fails to provide early and noisy warning of failure. Therefore, later studies tried to develop early identification model of financially troubled companies for some specific investigation purposes (Campbell et al., 2011; Gulsun and Umit, 2010) and also started to use the term financial distress. Also Sebestova, Sperka, Cemerkova (2016) (among other factors) also stressed the dilemma of survival and growth in current state of business environment. I addition, the bankruptcy literature reveals a high number of bankruptcy prediction models, mostly based on financial symptoms, but not on the more fundamental causes of failure. Publications concerning these causes, on the other hand, generally examine only a limited number of nonfinancial causes or focus on specific types of enterprises. Therefore, Sun et al. (2014) recommended that future studies should not define financial distress using a single criterion. They argued that financial distress should be segregated by the degree of adversity such as mild, intermediate and severe financial distress. Prediction of such adversity-based financial distress will help the stakeholder to take remedial measures more accurately. Tobback et al. (2017) also pointed out that research on bankruptcy prediction has largely focused on traditional data such as financial ratios, stock data and macroeconomic data. However, it is often noted that also the (in)competence of the managerial team has a great influence on a company's chance of survival. To measure a business manager's or board member's competence, one could take a look at the business history of this person. When a person was involved in a bankruptcy case in the past, banks will be reluctant to grant this person a loan for the start-up of a new company. Notwithstanding the clear importance of the management's competence and historical success/failure, most research on bankruptcy prediction does not take this kind of data into account. According to their research based on the sample of Belgian and UK companies using traditional and relational data (e. g. links between companies at the board and management level), the results confirmed the large predictive value of 
relational data and demonstrated that this mostly unused data source should be considered when developing bankruptcy prediction models. However, financial data seem to remain the most important source of information for the identification of financial distress.

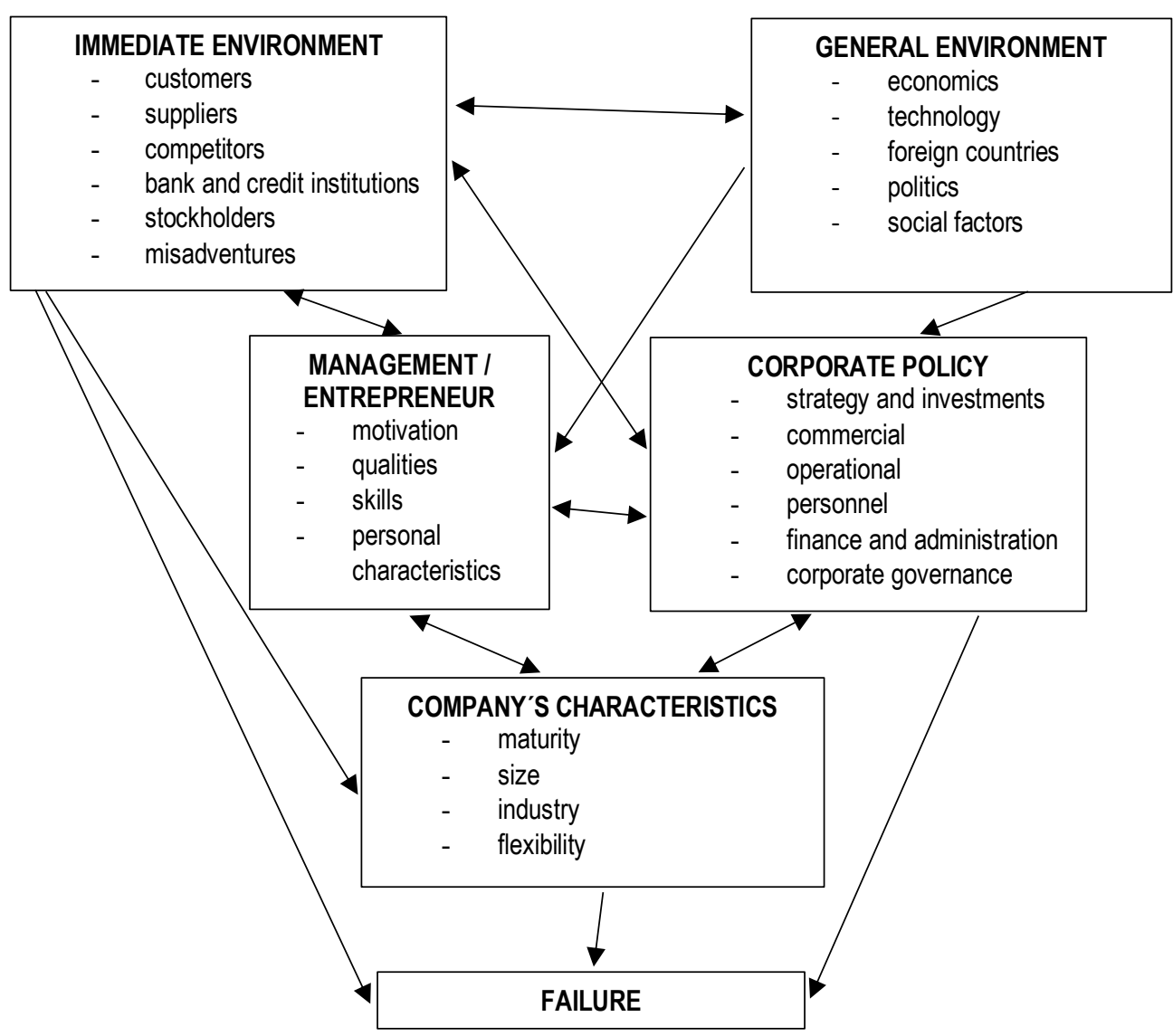

Figure 1. Conceptual failure model of possible causes of bankruptcy

Source: Ooghe, Waeyaert, 2004, In Ooghe Prijcker, 2006, p. 225

Methodology and research methods. As the bankruptcy was defined as the forced form of business termination, the primary objective of this paper is to analyse the evolution of the bankruptcy as a type of critical situation in Slovak companies from the regional and sectoral point of view, with focus given to the periods prior to bankruptcy. The paper utilizes secondary data obtained from the register of financial statements and finstat.sk database, specifically from its registry of critical situations (list of companies with pre-defined types of failures - bankruptcy, deficiency, cancellation) and registry of financial data.

The initial analysis was performed on the full-scale sample of entities entering bankruptcy process in the period from 2009 until 2019 and kept in evidence of above mentioned databases. Its partial objective was to analyse development of bankruptcies over time, its duration and regional and sectoral distribution. The total population of entities considered was as following. 
Table 1. Total population and research sample

\begin{tabular}{|l|c|c|c|}
\hline & $\mathbf{1 9 9 5 - 2 0 1 9}$ & $\mathbf{2 0 0 9 - 2 0 1 9}$ & $\mathbf{2 0 1 3 - 2 0 1 9}$ \\
\hline Total bankruptcies* & 14890 & 10768 & 9667 \\
\hline Unidentified start & 3626 & - & - \\
\hline Unidentified finish & 6189 & 4509 & 3955 \\
\hline Start and finish & 6483 & 5488 & 3631 \\
\hline
\end{tabular}

${ }^{*}$ all types of business entities

** not registered cancellation or still running bankruptcy process

Source: own processing

Although the register of critical situations is dated back to 1995, it does not cover fully the companies and processes finished before 2013 when the register of financial statements was introduced (data from 2009 until 2012 were uploaded there additionally, new data since then automatically uploaded after the declaration of taxes and annual statement of finances). Moreover, it involves also entities without data that became irrelevant in case of more detailed analysis. Thus, the second stage of research was limited as to the extent of population and data and therefore it was necessary to adjust the research sample. In order to minimize errors and misinterpretations, it was necessary to exclude from the total population from Table 1:

- $\quad$ sole traders (as those do not disclose financial data),

- companies without complete data (incomplete financial statements, mostly those missing total values),

- $\quad$ unidentifiable companies (missing or incorrect registered numbers),

- $\quad$ companies with unidentifiable bankruptcy process (missing information about the start or finish of the bankruptcy).

Finally, the sample included companies with already finished bankruptcy processes and covered the period from 2013 until 2019 (in this period the bankruptcy was started and finished, therefore, in reality, no 2019 data occurred, as such bankruptcy did not finish yet) aiming to analyse three consequent years before the start of bankruptcy (year b-1, b-2, b-3) in order to identify the development of potential distress situation leading to a bankruptcy.

Anyway, as the analysis covered preferably three years before the start of bankruptcy, some companies were included into research sample even though they missed some data from that period (were inactive for some reason or company was established less than three years before its bankruptcy) from that period. Therefore, in case of individual indicators, the number of companies in the sample was not equal over the analysed years (and also within the analysed year some indicators were missed as the company did not keep records about every item). The average annual count was 245 . In case of research samples' characteristics, all indicators were processed and interpreted as median values in order to minimize the influence of outlier values in individual ratios, economic life and bankruptcy duration were interpreted as averages. Descriptive statistics was oriented at:

- absolute indicators - sales, costs, profit/loss, equity,

- $\quad$ relative indicators - cash ratio, current ratio, debt-to-asset ratio.

The paper utilizes ordinary methods as the induction and deduction, analysis and synthesis, mathematical, statistical and graphical methods. The analysis includes classification, relation and causal analysis. All indicators were processed and the median values were interpreted as per each group of companies, sector or region. Shapiro-Wilk test was used for testing of normality distribution. Statistically significant differences between regions and selected SK NACE sectors were tested through the KruskalWallis test in the 2nd stage of the research. Pearson's correlation coefficient was used for the analysis of relations between numerical financial indicators. 
Above mentioned methods were used also within the testing of hypotheses. Each hypothesis corresponded with appropriate partial objective.

Table 2. Formulation of partial objectives and hypotheses

\begin{tabular}{|l|l|l|}
\hline Objective & \multicolumn{1}{|c|}{ Main Hypothesis } & \multicolumn{1}{c|}{ Alternative Hypothesis } \\
\hline $\begin{array}{l}\text { O1-To quantify the length } \\
\text { of bankruptcy processes }\end{array}$ & $\begin{array}{l}\text { There is no statistically significant } \\
\text { difference between lengths of } \\
\text { bankruptcy processes in companies } \\
\text { from different sectors (H1a) and regions } \\
(\mathrm{H} 1 \mathrm{~b}) .\end{array}$ & $\begin{array}{l}\text { There is a statistically significant } \\
\text { difference between lengths of } \\
\text { bankruptcy processes in companies } \\
\text { from different sectors. }\end{array}$ \\
\cline { 2 - 4 } $\begin{array}{l}\text { Debt-to-assets ratio significantly } \\
\text { influences the length of bankruptcy (H2). }\end{array}$ & $\begin{array}{l}\text { Debt-to-assets and length of bankruptcy } \\
\text { are irrelevant. }\end{array}$ \\
\hline $\begin{array}{l}\text { O2 - To analyze economic } \\
\text { and financial conditions } \\
\text { before the start of } \\
\text { bankruptcy }\end{array}$ & $\begin{array}{l}\text { The bankruptcy process is initiated } \\
\text { primarily due to the lack of liquidity (H3). }\end{array}$ & $\begin{array}{l}\text { The bankruptcy process is initiated } \\
\text { primarily due to the indebtedness. }\end{array}$ \\
\hline
\end{tabular}

Source: own processing

Results. The first part of the research was focused on identification of entities entering bankruptcy process in the time scope from 2009 to 2019. There were 10768 bankruptcies in this period, from which 4509 had unidentified finish (not properly recorded or still running) and 5488 started and finished as well. Total number of bankruptcy operations includes both legal entities and sole traders, among them the share of sole traders overwhelmed (generally they reached $58 \%$ when summarizing all kinds of processes in register of critical situations from an administrative point of view - declarations, announcements, including opening and closing of bankruptcy).

As to the entity type, during 10 years' period, the share of legal entities (subjects) entering bankruptcy was about $18 \%$. The highest number of bankruptcies was reached in Banska Bystrica region $(21,29 \%)$, followed by Bratislava region with $14 \%$ share. The lowest share was found in Trnava region (7,16 \%). Bratislava is the only region in which the share of legal entities was higher than the share of sole traders (this corresponds with the structure of entities - in Bratislava region the relation between legal entities and sole traders was about $60: 40$, in Banska Bystrica $37: 63$ ).

On the other hand, the dynamics of increases changed a lot during the analysed period, Banska Bystrica region reached enormous increase of bankruptcies just in 2017 (more than $25 \%$ share on annual increase of bankruptcies, $24 \%$ in 2018), otherwise Bratislava would be the region with the highest share (as was before these changes).

Distribution of bankruptcies over the regions is strongly interconnected with ultimate business closures. Those were previously proved to be correlated with general industrial and economic development, specifically with the number of businesses in all regions (Elexa, Hvolkova, Knapkova, 2018), specifically in case of legal entities in Kosice region with the moderate uphill relationship, in others with a weaker linear relationship.

In case of sectors, we can consider construction companies to be the absolute «winner» with more than $22 \%$ share on total bankruptcies. Although the share of retail trade companies is also significant, they are not so numerous as construction companies. The list continues with rather on services-oriented sectors with quite similar share (Figure 2). Not surprisingly, the share of industries considered to be the backbone of Slovak economy was very low (car production, electrical engineering, machinery), having less than $1 \%$ share. 


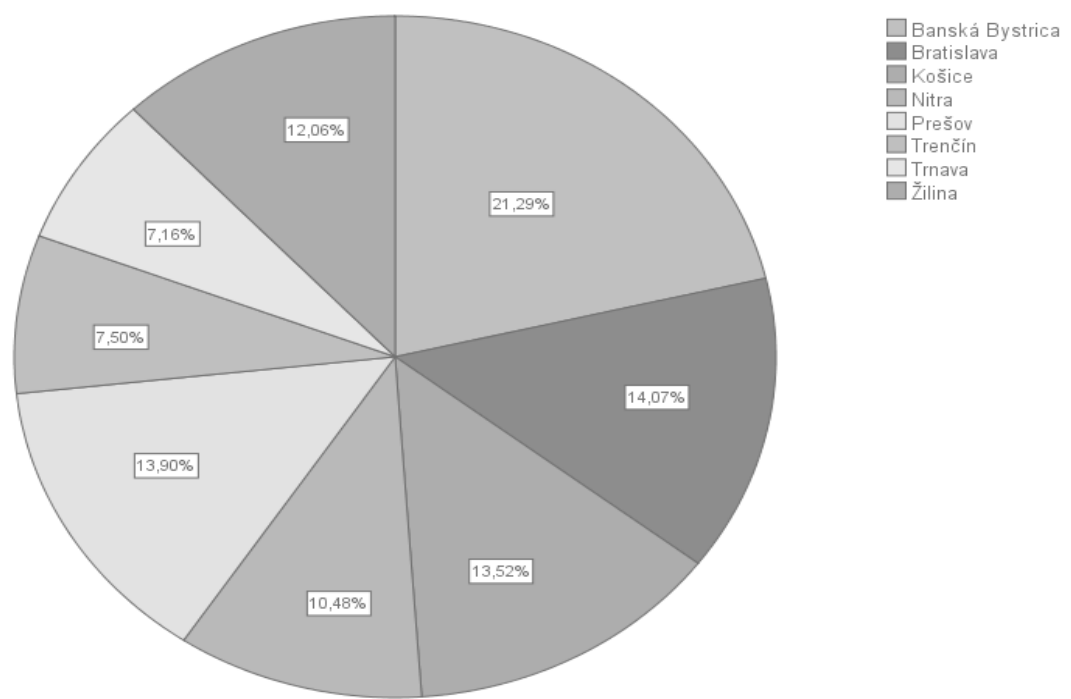

Figure 2. Regional distribution of bankruptcies

Source: own processing

As was already indicated in previous sectoral distribution, the most bankrupted sectors were quite distinctive. On the other hand, regional point of view on sectors proved two main facts: 1. bankruptcies «respected» the distribution of sectors in regions (agriculture, forestry, apparel and footwear, specific services were not evenly represented), 2. nation-wide most bankrupted industries showed normal distribution all over regions and dominated there as well (construction and retail trade).

Table 3. Sectoral distribution of bankruptcies

\begin{tabular}{|l|c|c|}
\hline & Frequency & Percent \\
\hline Construction & 2437 & 22,6 \\
\hline Retail trade & 1207 & 11,2 \\
\hline Agents involved in sale & 764 & 7,1 \\
\hline Manufacture of basic metals & 667 & 6,2 \\
\hline Transportation & 642 & 6,0 \\
\hline Accommodation and food service activities & 547 & 5,1 \\
\hline Financial services & 503 & 4,7 \\
\hline Agriculture and forestry & 499 & 4,6 \\
\hline Wholesale & 485 & 4,5 \\
\hline Manufacture of wood and paper & 317 & 2,9 \\
\hline Total & 10768 & 100,0 \\
\hline
\end{tabular}

Source: own processing

Bold figures in Table 4 show those shares that are «non-standard» when compared with other regions. Specifically, Bratislava region shows extraordinary share of services in sectors that are not so developed in other regions (publishing, real estates, legal and accounting services, advertising). It is no surprise because as the capital and financial centre it has all the prerequisites for similar economic structure, as well as it has poor conditions for development of forestry or manufacture of wood and paper (as has Nitra region too). 
Construction, retail trade and agents involved in sale were identified as the most bankrupted sectors in Slovakia, and are similarly distributed over all regions too. Construction has the highest share in seven out of eight regions, only in Bratislava retail trade overwhelmed. Shapiro-Wilk test proved that industries have normal distribution in regions, except of publishing, real estates, legal activities and advertising.

After non-statistical «cluster analysis» it may be stated that trading activities are generally the second most threatened and fluctuated sector (retail, wholesale, agents involved in sale) right after the construction, while manufacture is less vulnerable.

Table 4. Regional distribution of bankrupted sectors

\begin{tabular}{|c|c|c|c|c|c|c|c|c|}
\hline & BB & BA & KE & NR & PO & TN & TT & ZA \\
\hline $\begin{array}{l}\text { Accommodation and food service } \\
\text { activities }\end{array}$ & $4,4 \%$ & $7,0 \%$ & $4,7 \%$ & $5,0 \%$ & $4,5 \%$ & $6,1 \%$ & $6,9 \%$ & $3,7 \%$ \\
\hline Transportation & $5,7 \%$ & $8,6 \%$ & $5,9 \%$ & $6,6 \%$ & $3,9 \%$ & $5,0 \%$ & $7,5 \%$ & $4,9 \%$ \\
\hline Manufacture of wood and paper & $2,9 \%$ & $1,2 \%$ & $2,8 \%$ & $1,2 \%$ & $4,9 \%$ & $3,8 \%$ & $2,3 \%$ & $4,4 \%$ \\
\hline Financial services & $2,6 \%$ & $2,5 \%$ & $3,9 \%$ & $2,1 \%$ & $1,5 \%$ & $2,7 \%$ & $3,4 \%$ & $2,5 \%$ \\
\hline Manufacture of basic metals & $6,7 \%$ & $2,0 \%$ & $8,3 \%$ & $7,6 \%$ & $6,9 \%$ & $9,2 \%$ & $4,8 \%$ & $4,7 \%$ \\
\hline Retail trade & $10,2 \%$ & $13,7 \%$ & $12,2 \%$ & $11,6 \%$ & $9,6 \%$ & $12,4 \%$ & $9,7 \%$ & $10,5 \%$ \\
\hline Publishing and broadcasting & $0,6 \%$ & $2,4 \%$ & $0,9 \%$ & $0,5 \%$ & $0,8 \%$ & $0,6 \%$ & $0,4 \%$ & $0,9 \%$ \\
\hline Real estates & $1,2 \%$ & $5,0 \%$ & $1,5 \%$ & $0,8 \%$ & $1,8 \%$ & $1,0 \%$ & $1,9 \%$ & $1,3 \%$ \\
\hline $\begin{array}{l}\text { Manufacture of apparel and } \\
\text { footware }\end{array}$ & $1,3 \%$ & $1,1 \%$ & $1,4 \%$ & $1,5 \%$ & $2,3 \%$ & $2,1 \%$ & $1,7 \%$ & $1,4 \%$ \\
\hline Agriculture and forestry & $8,8 \%$ & $0,9 \%$ & $3,8 \%$ & $3,0 \%$ & $7,9 \%$ & $2,2 \%$ & $2,5 \%$ & $3,0 \%$ \\
\hline Legal and accounting activities & $1,3 \%$ & $6,1 \%$ & $1,4 \%$ & $1,9 \%$ & $1,7 \%$ & $1,9 \%$ & $1,6 \%$ & $1,5 \%$ \\
\hline Advertising and market research & $0,9 \%$ & $2,6 \%$ & $1,0 \%$ & $1,0 \%$ & $0,8 \%$ & $0,4 \%$ & $1,2 \%$ & $0,3 \%$ \\
\hline Agents involved in sale & $6,1 \%$ & $7,5 \%$ & $8,1 \%$ & $10,5 \%$ & $5,3 \%$ & $6,9 \%$ & $5,3 \%$ & $7,5 \%$ \\
\hline Construction & $24,8 \%$ & $11,2 \%$ & $17,9 \%$ & $20,5 \%$ & $27,9 \%$ & $23,3 \%$ & $23,2 \%$ & $32,5 \%$ \\
\hline Wholesale & $2,9 \%$ & $6,2 \%$ & $6,1 \%$ & $4,3 \%$ & $4,3 \%$ & $3,2 \%$ & $4,8 \%$ & $4,5 \%$ \\
\hline
\end{tabular}

Source: own processing

Dramatic change in the development of bankruptcies was observed since 2017. Rapid increase was similarly expressed all over sectors and regions. The amendment of bankruptcy legislation was the main reason of such trend, specifically the introduction of so called «small bankruptcy» and general simplification of necessary processes. Following charts indicate just the development in retail trade and construction industry to demonstrate the full effect of changes (although they can't be compared each other, as the monthly increase in retail was about 80 bankruptcies, while in construction almost 300).

Although the increase in 2017 was enormous, those bankruptcies were obviously not finished yet, thus they did not influence the character of processes and the duration of bankruptcies included into research sample.

Generally, the economic life of companies entering bankruptcy since 2009 reached 12,26 years (as of May 22, 2019) including both running and finished bankruptcies, with standard deviation of 7 years. The minimal duration of company's life was 1,6 year and maximum was 53,5. Companies from electrical engineering (20 years), agriculture (21 years) and project and engineering services ( 26 years) reached the longest economic life, first two sectors as representants of rather traditional industries in Slovakia. The youngest were companies from advertising, legal and accounting services and accommodation and food services (11 years each). Companies from Žilina region are the oldest ones (17,6 years), while in Bratislava region the economic life is more dynamic and companies younger (12,6 years). 

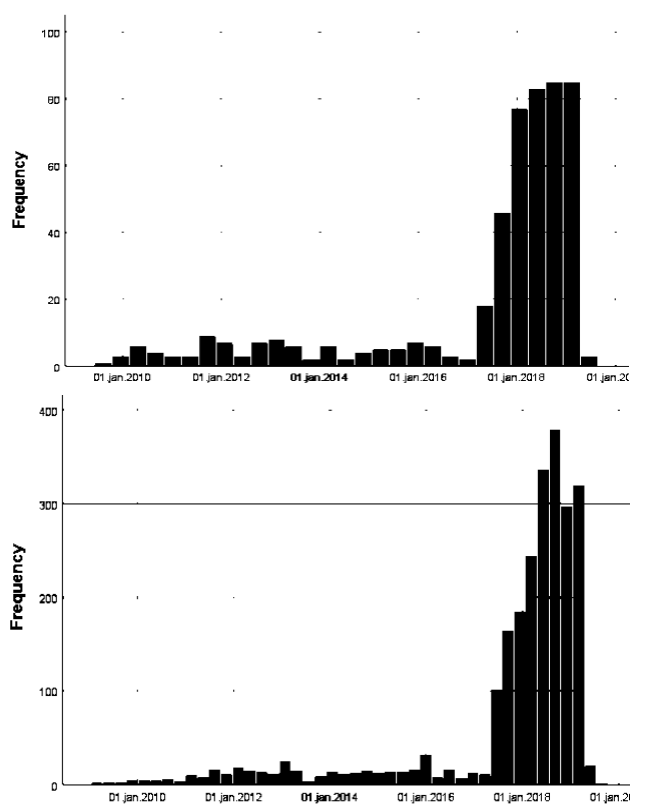

Figure 3. Development of bankruptcies in time

Source: own processing

In case of already closed bankruptcies, they generally lasted for 2,64 years with standard deviation of 1,5 years. The shortest bankruptcy endured for 38 days, while the longest for 5,9 years. These numbers were cumulated for bankruptcies already finished. Within them the bankruptcy process was the shortest in IT services (less than a year), while in accommodation and food services it took almost 4 years.

Table 5. Duration of bankruptcy (in years)

\begin{tabular}{|l|c|l|c|}
\hline Sector & $\begin{array}{c}\text { Bankruptcy } \\
\text { duration }\end{array}$ & Sector & $\begin{array}{c}\text { Bankruptcy } \\
\text { duration }\end{array}$ \\
\hline Accommodation and food services & 3,83 & Agriculture and forestry & 2,8 \\
\hline Transportation & 2,86 & IT services & 0,91 \\
\hline Manufacture of wood and paper & 3,20 & Agents involved in sale & 1,7 \\
\hline Financial services & 3,12 & Construction & 2,15 \\
\hline Retail trade & 3,24 & Wholesale & 2,44 \\
\hline
\end{tabular}

Source: own processing

Bankruptcy process took the longest time in Presov region (3,4 years), while in Trencin region it took just 1,8 years. Pearson correlation coefficient showed no relationship between the number of bankruptcies and their duration $(r=0,028)$ and low downhill linear relationship between duration of bankruptcy and number of judges at the court $(-0,108)$ in each region.

Current legislation in Slovakia understands two types of proceedings for companies in financial distress, from which just bankruptcy (restructuring is the second one) is the object of this paper. In case of bankruptcy there exist two ways of its initiation (Act No. 7/2005 Coll., Bankruptcy and Restructuring Act):

- company is considered illiquid if it is unable to pay its debts for more than 30 days after their due date and has at least two obligations in favour of at least two creditors, 
- company is over-indebted if its liabilities exceed its total assets and it has more than one creditor.

Next part of the analysis focuses on the development of these two issues three years before the start of bankruptcy. Analytical steps start with absolute indicators (sales, profit, equity) and continue with liquidity and debt-to-assets ratios as their outcomes.

While three years before entering the bankruptcy the sales went down by $17 \%$, two years before it fell by $25 \%$ and finally by $36 \%$ one year before the bankruptcy. It points out to a fact that there were either market problems (less successful sale) or internal problems (cost efficiency). We may declare that first reason seems to be relevant, as the material consumption went down (7\% three years before bankruptcy, then $18 \%$ and finally $54 \%$ ) and personal cost as well (33\% a year before). On the other hand, current ratio (involving inventories) one year before bankruptcy went up (from 0,27 to 0,43 ) obviously because of inventories, while cash ratio and acid test (without inventories) decreased. So it emphasized the redundancy of inventories and their influence on efficiency, including liquidity (at the same time it proves the continuation of production, which, if stopped, could be considered as the primary reason of decrease in costs).

Decreased sales and decreased consumption may be questionable as to the cumulative effect, so it is necessary to understand also the development of profit and its consequent influence on equity. While three years before bankruptcy the share of lossy companies was $34 \%$, two years before it was $53 \%$, but one year before it was $43 \%$ (partially the sale of assets helped - Figure 4). Final improvement may seem positive, but the change in return on assets (from $-13 \%$ to $-51 \%$ ) indicates that the share of lossy companies went down but the volume of loss significantly grew (when compared with assets).

All these processes have significant influence on development of liquidity which is mentioned as the first initiator of bankruptcy. Cash ratio three years before bankruptcy was $0,9 \%$, two years later it was just $0,2 \%$ (share of cash and cash equivalents on short-term debt). So obviously financial accounts are hardly comparable with the value of short-term debt and companies became insolvent. This fact is supported also through the development of daily sales in receivables (those went down, partially due to the lower sales mentioned above) and daily sales in trade payables (worsened from 119 days three years before, through 130 days, to 182 days one year before the bankruptcy).

Similarly, the second bankruptcy rule (indebtedness or negative equity) was investigated, significantly interconnected with above mentioned profitability (or loss).

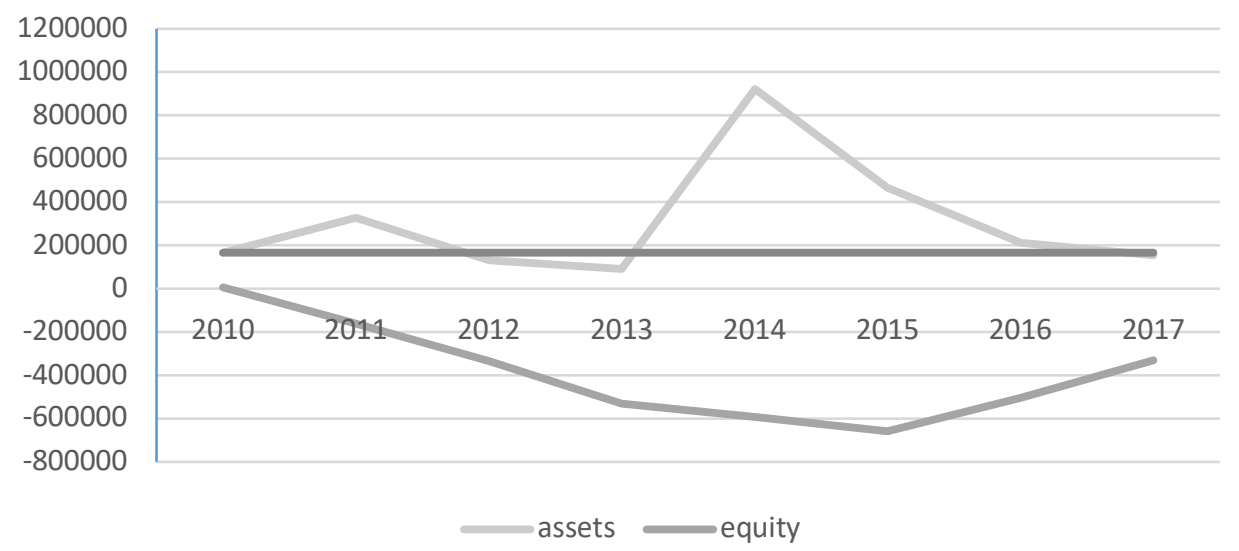

Figure 4. Development of assets and equity in long-term period

Source: own processing 
Generally, when having 2010 values as a benchmark (straight line in chart), average values of assets in bankrupted companies after short stagnation reached their peak in 2014 and then rapidly went down. At the same time, in line with Bankruptcy and Restructuring Act, the equity decreased and reached even more negative values and then grew a bit. Certain growth (or mitigation of loss) in equity may be clarified in two ways - firstly through the significantly improved earnings (from 2,1 mil. € cumulated for all entities in the sample two years before the bankruptcy up to 9,1 mil. $€$ one year before bankruptcy) and secondly through the amortization of accumulated losses that partially cut its size (in profitable companies).

As this development involved data from the whole analysed period and represent long-term trend, we measured the dynamics through the pre-bankruptcy period as well. During last two years the assets value went down by $30 \%$. Such numbers exceed ordinary straight-lined depreciation (in case of long-term assets) and may be understood also as a signal of conversion of assets into cash (as it was proved through the recorded sales from long-term assets) or decrease in short-term assets (mostly decrease of cash that is, on the other hand, usually not so significant when compared with the volume of total assets).

In case of equity, there were 46 companies having negative equity three years before, but one year prior to bankruptcy this number more than doubled (95 companies). Therefore, it seems that almost in half of the companies the equity is not considered to be a bankruptcy initiator. The most companies with negative equity were in Bratislava region (28\% share), on the other hand, Trnava region had just $3 \%$ share. As a reason leading to a bankruptcy from regional point of view we may (just hypothetically) state that in Nitra region there were $65 \%$ bankrupted companies suffering from negative equity, but in Kosice region just $19 \%$ of bankrupted companies generated negative equity.

On the other hand, negative equity led companies to be indebted, having total debt-to-assets indicator of $589 \%$ one year before bankruptcy (after certain improvement from $851 \%$ due to the change in equity indicated in Figure 4).

Conclusions. Bankruptcy is considered in Slovak legislation as a terminal solution in case of financial distress. After the start of bankruptcy proceedings, the bankrupted subjects are supposed to restrain ordinary activities, on the other hand, they are protected from the execution. Since 2016 the Act on Bankruptcy undergone significant changes, because of which were a) «small bankruptcies» simplified, b) restructuralisation was tighten up. Consequently, many companies formerly supposed to enter restructuring and many individuals that were suddenly allowed to, started bankruptcy process. At the same time significant changes were amended also in execution procedure. All these legislative measures finally caused so enormous increase of bankruptcies in 2017 with so dominating share of sole traders. It should be stated that small bankruptcy is open also for non-entrepreneurs but such individuals were not involved into whatever research sample mentioned in this paper.

The median value of economic life of bankrupted companies was 12,26 years, the longest in engineering services ( 26 years) and in Žilina region $(17,6)$. The median value of bankruptcy process was 2,64 years, the longest was in accommodation services $(3,8)$ and in Presov region, the shortest in IT services $(0,9)$ and Trencin region.

In first hypothesis we supposed that there is no statistically significant difference between lengths of bankruptcy processes of companies from different sectors $(\mathrm{H} 1 \mathrm{a})$ and regions $(\mathrm{H} 1 \mathrm{~b})$. According to the results of Kruskall-Wallis test we may state that this hypothesis is not rejected $(p=0,059)$ in case of sectors, while in case of regions the alternative hypothesis was adopted and we consider differences between them as significant $(p=0,022)$ at the significance level of 0,05 .

In second hypothesis it was supposed that debt-to-assets ratio significantly influences the length of bankruptcy $(\mathrm{H} 2)$, expecting that high debt leverage limits the ability to cover all claims. The results of correlation analysis and Pearson's coefficient $(r=-0,116)$ proved this expectation to be correct but not so significant. Weak downhill linear relationship means that higher is the ratio the lower is the duration of the bankruptcy. 
In the third hypothesis, we supposed that the bankruptcy process is initiated primarily due to the lack of liquidity $(\mathrm{H} 3)$. In reality the level of solvency went down and companies were able to cover their current debts with cash and cash equivalents just on $0,2 \%$. One year before the bankruptcy only $4,8 \%$ of the companies were considered to have sufficient liquidity (when considering $20 \%$ of short-term debt coverage as the necessary minimum). On the other hand, daily sales in trade payables were prolonged up to 182 days. Meanwhile, $50 \%$ of the bankrupted companies were indebted (with negative equity) one year before bankruptcy, having the debt in the size of $589 \%$ of their assets. Although the law expects (when having the knowledge about indebtedness) that the debtor should adopt necessary measures in order to avoid a potential bankruptcy, the number of companies with negative equity worsen. Based on this we do not reject $\mathrm{H} 3$ and declare that lack of liquidity is the dominant factor (for more detailed evaluation it would be perfect to know in each case who was the really initiating subject of the bankruptcy, as the financial data offers just static information and in the reality bankrupted company may suffer from insolvency and indebtedness at the same time).

It would be interesting also to analyze the life cycle through the bankruptcy process, but in line with Accountancy Act 431/2002 Coll. as amended by the Act 562/2003 Coll., and by the Act 561/2004 Coll. legal entities shall close their books of accounts always as of the effective date of a bankruptcy order and as of the date, on which the decision to recall the bankruptcy proceedings becomes final and nonappealable. Thus the longer the bankruptcy lasts the more the absence of data limits the understanding of changes and the level of debt extinction. Therefore, disclosed statements so helpful in case of static analysis of economic and financial conditions are not effective during the bankruptcy and do not catch up dynamic sufficiently the development during bankruptcy processes. This may be considered as very important limitation of our research. Another one, not so intense, was the absence of historical data caused by the registry creation. Also the analysis in long-term conditions may be a crucial limitation as every bankruptcy (or bankruptcies) are realized in different era, thus are having different economic and legislative conditions, which may have significant impact on their sales, earnings, consequent ratios and bankruptcy acts and procedure. On the other hand, recent changes in legislation influenced the conditions for the bankruptcy processes which means that after their conclusion it would be possible to confront the situation before and after the amendment.

Author Contributions: It is estimated that each author contributed with equal share to the preparation of research and finalization of paper. The outline of paper was prepared by L. E. and L. H. M. K. wrote abstract and did the formal analysis. L. H. and M.K. prepared theoretical background and literature review. L. E. provided data, prepared methodology and final validation. L. H. performed the visualization of results and final editing. L. E. and L. H. wrote discussion. M. K. was responsible for references check.

Funding: The paper was supported by: the project VEGA no. 1/0468/18 «The analysis of bankruptcy of small and medium sized enterprises in Slovakia»; Minister of Science and Higher Education titled "Regional Initiative of Excellence" in 2019-2022, project number 018/RID/2018/19, the amount of funding PLN 10788423,16

\section{References}

Accountancy Act 431/2002 Coll., of June 18, 2002, as amended by the Act 562/2003 Coll., and by the Act 561/2004 Coll. (Slovakia).

Act No. 7/2005 Coll., Bankruptcy and Restructuring Act of December 9, 2004, as amended by later acts (Slovakia).

Boeker, W. (1997). Strategic change: the influence of managerial characteristics and organizational growth. Academy of Management Journal, 4a1), 152-70. doi: 10.2307/257024

Bradley, D.B., Cowdery, Ch. (2002). Small Business: Causes of Bankruptcy. Retrieved from http://citeseerx.ist.psu.edu/viewdoc/download?doi=10.1.1.367.4484\&rep=rep1\&type=pdf 
Bryan, D., Fernando, G.D., Tripathy, A. (2013). Bankruptcy risk, productivity and firm strategy. Review of Accounting and Finance, 1244), 309-326. doi: 10.1108/RAF-06-2012-0052

Campbell, J., Hilscher, J., Szilagyi, J. (2011). Predicting financial distress and the performance of distressed stocks. Journal of Investment Management, 92), 14-34.

Database of financial data. (2019, April 12). Retrieved from https://www.finstat.sk 56-68.

Elexa, L., Hvolkova, L., Knapkova, M. (2018). Úpadok ako potencialny nasledok nevhodných inovacii. Acta Aerarii Publici 15(2),

Farooq, U., Qamar, M.A.J., Haque, A. (2018). A three-stage dynamic model of financial distress. Managerial Finance, 44(9), 1101-1116. doi: 10.1108/mf-07-2017-0244

Gulsun, I., Umit, G. (2010). Early warning model with statistical analysis procedures in Turkish insurance companies. African Journal of Business Management, 4(5), 623-630.

Korol, T., Korodi, A. (2010). Predicting bankruptcy with the use of macroeconomic variables. Economic Computation and Economic Cybernetics Studies and Research, 44(1), 201-221.

Ooghe, H, Prijcker, S. (2006). Failure processes and causes of company bankruptcy: a typology. Management Decision, 46(2), 223-242. doi: 10.1108/00251740810854131

Opoku, K., Amon, A., Arthur, C.J. (2015). Predicting corporate failure: a systematic literature review of methodological issues. International Journal of Law and Management, 575), 461-485. doi: 10.1108/IJLMA-04-2014-0032

Parrino, R., Poteshman, A.M., Weisbach, M.S. (2005). Measuring investment distortions when risk-averse managers decide whether to undertake risky projects. Financial Management, 34(1), 21-60. doi: 10.2139/ssrn.297779

Pindado, J., Rodrigues, L., Torre, C. (2008). Estimating financial distress likelihood. Journal of Business Research, 61(9), 995-1003. doi: 10.2139/ssrn.485182

Purnanandam, A.K. (2008). Financial distress and corporate risk management: theory \& evidence. Journal of Financial Economics, 873), 706-739. doi: 10.1016/j.jineco.2007.04.003

Register of financial statements. (2019, April 25). Retrieved from https://registeruz.sk

Sun, J., Li, H., Huang, Q.-H., He, K.-Y. (2014). Predicting financial distress and corporate failure: a review from the state-of-theart definitions, modeling, sampling, and featuring approaches. Knowledge-Based Systems, 57, 41-56. doi:10.1016/j.knosys.2013.12.006

Sebestova, J., Sperka, R., Cemerkova, S. (2016). Determinants of regional business environment in Czech Republic: an expert dilemma. Forum Scientiae Oeconomia, 4(4), 65-74.

The review of regional courts. (2018, December 31). Retrieved from https://www.justice.gov.sk/Stranky/Sudy/Statistikasudy.aspx

Tobback, E. et al. (2017). Bankruptcy prediction for SMEs using relational data. Decision Support System, 102, 69-81. doi:10.1016/j.dss.2017.07.004

Любос Елекса, Ph.D., Університет Матея Бел (Словаччина);

Ленка Хволкова, Ph.D., Університет Матея Бел (Словаччина);

Мирослава Кнапкова, Ph.D., Університет Матея Бел (Словаччина).

Антикризове управління: перші сигнали банкрутства

Кризові ситуації в операційній діяльності компанії мають свою закономірність та тенденцію розвитку. При цьому кризи, які можна подолати та неминучі кризи відрізняються за своєю тривалістю, залежать від сектору економіки та регіону в якому функціонує підприємство. У Свою чергу подолання кризових ситуацій вимагає відповідного юридичного втручання. Авторами визначено, що негативним наслідком кризи на підприємстві $\epsilon$ банкрутство. Швидке зростання кількості банкрутств на підприємствах Словаччині обумовлює актуальність дослідження. Головною метою статті $є$ аналіз процесу банкрутства як одного із виду кризи в компаніях Словаччини, виокремлення його характеристики за регіональними та галузевими особливостями, враховуючи економічні умови функціонування перед початком банкрутства. У статті використано вторинні дані, отримані із наявних баз даних. При цьому дослідження проведено на основі панельних даних, сформованих для вибірки із усіх компаній, що знаходяться на перших етапах банкрутства з 2009 до 2019 року. На першому етапі сформовано та проаналізовано генеральну сукупність компаній незалежно від форми власності з метою визначення інтенсивності банкрутств в залежності від сектору економіки та регіону, в якому функціонують підприємства. На другому етапі виокремлено цільову вибірку за допомогою виключення нерелевантних компаній - приватних підприємців без наявної інформації про ї діяльність, а також компанії із непідтвердженою інформацією чи незрозумілими причинами початку процесу банкрутства. Таким чином, у статті визначено ранні попереджувальні сигнали банкрутства за допомогою абсолютних та відносних показників за три, два та рік до початку банкрутства. Авторами кількісно визначена та детально тривалість процесу банкрутства для відповідних секторів економіки (визначених за Європейською класифікацією економічної активності) та регіонів Словаччини. Результати емпіричного аналізу свідчать про те, що різке зростання кількості банкрутств відбулось під час істотних змін у законодавстві про банкрутство. У статті встановлено, що найдовший процес банкрутства (4 роки) 
зафіксований у готельному та ресторанному бізнесі, тоді як ІТ компанії, загалом, виходять із ситуації банкрутства протягом року. Авторами наголошено, що тривалість банкрутства не має статистично значущої різниці між секторами економіки та регіонами в яких функціонує підприємство. При цьому відповідно до законодавчих норм, низький коефіцієнт ліквідності вважається головною причиною зародження банкрутства у компанії. Отримані результати дослідження мають практичне значення і можуть бути корисними для подальшого детального аналізу взаємозв'язку між розвитком процесу банкрутства, компенсацією зобов'язань та нефінансовими факторами банкрутства в окремих секторах економіки.

Ключові слова: банкрутство, неплатоспроможність, заборгованість, внутрішні фактори, життєвий цикл, ліквідність.

Manuscript received: 27.06.2019.

(C) The author(s) 2019. This article is published with open access at Sumy State University. 